\title{
BIOLOGICAL CONTROL OF AGRICULTURAL PESTS BY FILAMENTOUS FUNGI
}

\author{
L. MANCZINGER
}

Department of Microbiology, Attila József University, Szeged, Hungary

Agricultural use of chemical pesticides has polluted the environment and resulted in resistance among the target organisms. The chemical strategies of pest control are dangerous to both the nontarget organisms in natural habitats and human health. Biological control is an attractive less dangerous possibility for controlling plant pathogens.

Some methods of biological control are becoming now commercially available against plant parasitic fungi, nematods and insects. Among filamentous fungi many candidates with biocontrol potential can be found. Fungal biocontrol agents are less effective and reliable than the synthetic pesticides therefore their use in the agricultural practice requires genetic improvement.

\section{Mycofungicides}

There are many fungal genera, which contain species, which effectively antagonize and/or parasitize plant parasitic fungi both in the rhizosphere and phyllosphere [1].

The most effective species can be found in Trichoderma, Gliocladium, Fusarium, Talaromyces, Ampelomyces and Coniothyrium genera.

Mycoparasitic Trichoderma and Gliocladium strains could be used to control a wide range of plant-pathogenic fungi e.g. Pythium, Rhizoctonia, Fusarium and Botrytis.

The ecological, physiological and molecular aspects of biocontrol by these fungi were recently reviewed $[2-5,77-78,80]$.

Alternative mechanisms may be responsible for the control effects of these species. Some strains of them are able to produce antifungal antibiotics [6-7], which may have synergistic effect with extracellular fungal-cell-wall degrading extracellular enzymes [8].

The production of cell-wall hydrolyzing enzymes seems to be the most important factor of antagonism. Both Trichoderma and Gliocladium mycoparasitic strains in some cases constitutively secrete high amounts of $\beta-1,3$-glucanases [9], chitinases [10-11] and proteases [12]. The other important phenomenon of mycoparasitic strains is the capability for the production of appressoria which penetrate the cell wall of the target fungus and

LÁSZLÓ MANCZINGER

Department of Microbiology, Attila József University

P.O. Box 533, H-6701 Szeged, Hungary 
grow inside the target cells. The production of appressoria is an inductive process which require the presence of specific lectins in the cell wall of the target fungus [13]. There are reports that the cell-wall-degrading enzymes act synergistically in the cell-wall hydrolyzing process. Several different enzymes, chitinases, $\beta$-1,3-glucanases, $\beta-1,6$ glucanases and proteases have been purified from the inductive ferment brothes of Trichoderma [14-17] and Gliocladium [8] mycoparasitic strains. From the purified enzymes chitinases and $\beta-1,3$-glucanases showed the most intensive spore-germination inhibitory effect.

The purified degradative enzymes acted synergistically not only with each the other, but also with antibiotics and chemical pesticides [18-19]. Many Trichoderma and Gliocladium biocontrol strains could be originally resistant against a wide variety of chemical fungicides frequently used for controlling phytopathogenic fungi.

Combining fungicide resistant biocontrol strains with chemical fungicides could results in decreased fungicide level in soils. This is the base of integrated pest management which cold be very effective, but less dangerous to the ecosystem and human health than the chemical control alone [3].

In some cases the biocontrol strains are also sensitive to the fungicide to be applied (e.g. to the frequently used fungicide benomyl); in this case resistant strains could be isolated by induced mutagenesis [20].

An effective pest control may require $10^{5}-10^{6}$ propagula to be present in one gram soil in the case of Trichoderma and Gliocladium [2]. These high amounts of conidia to be present are not desirable either of ecological and economical or public health of aspects.

To solve this problem the biocontrol strains of Trichoderma and Gliocladium should breed for more effective.

Strains, which do not require a long inductive process for production of degradative enzymes, could be more effective biocontrol agents. Generally the biocontrol strains produce $\beta$-1,3-glucanases constitutively, some elements of chitinase systems require induction and the most effective proteases are also produced inductively [12, 21].

Only a limited number of publications deal with mycoparasitic strains obtained by mutagenesis. Some of these investigations report on random isolate tests following only mutagenetic treatments, others publish on obtaining fungicide resistant mutants which could be used in integrated pest management and only some of them deal with true targeted mutagenetic improvement of the enzyme secretion abilities of the strains [22-23].

The mutagenetic methods of breeding are worth to bigger attention as these strains could get registration more easily for on field use from environmental protection agencies than the strains, which are produced by protoplast fusion, transformation or via gene cloning.

Protoplast fusion is a quick and easy method for combining the advantageous properties of distinct promising strains. It was successfully applied for the breeding of $T$. harzianum biocontrol strains [24-25]. The parasexual cycle of Trichoderma has some interesting phenomenons, which were first published in T. reesei [26]. The parameiotic behaviour was later also published for T. harzianum and T. viride [27]. Protoplast could be easily produced from the biocontrol Trichoderma strains and their induced fusion resulted in genetic recombinants with elevated biocontrol abilities in many instances [28]. Many publications deal with the transformation methodology of Trichoderma and 
Gliocladium strains. Some of the most frequently applied methods use fungicide resistance, others auxotrophic-complementing or acetamid-catabolitic genes for transformation [29, 67-68, 75-76]. Transformation for benomyl resistance interestingly never resulted in high transformation frequencies even if homologous system was used. The use of hygromycin B selection systems resulted in the highest transformation frequencies. These frequencies were even more elevated if spermin was present in the transformation mixture [29]. Many Gliocladium and Trichoderma strains are originally resistant to hygromycin $\mathrm{B}$. In these cases the acetamidase or auxotrophic complementation methods could be used.

Many publications are dealing with the cloning of structural genes of enzymes important in the mycoparasitic process. Most frequently chitinase genes have been cloned [30-35].

In some cases protease [36] and a $\beta$-1,3-glucanase [37] genes were also successfully cloned from mycoparasitic strains.

The cloned genes in some cases with new constitutive promoters were transformed into Trichoderma strains. More efficient biocontrol strains could be found among the transformants [38].

There are many ecological factors which could disturb the effectiveness of biocontrol strains in soils: e.g. other Trichoderma strains [39], bacteria [40], low temperature [41] and ionic composition. A more intensive investigation of these fields is very important for the effective practical use of the wild type and the breeded strains.

In on field investigation the monitoring of the biocontrol strains in soils is also very important.

For these purposes resistance markers, RFLP analysis, DNA fingerprinting, PCR and RAPD techniques could be used efficiently [42-44].

Table I

Commercial biocontrol products for use against plant-pathogenic fungi

\begin{tabular}{ll}
\hline Biocontrol fungus & Product Name \\
\hline Ampelomyces quisqualis & AQ10 \\
Coniothyrium minitans & Contans \\
Fusarium oxysporum & Biofox C, Fusaclean \\
Gliocladium virens & SoilGard (Formerly GlioGard) \\
Phlebia gigantea & Rotstop, P.g. Suspension \\
Pythium oligandrum & Polygandron \\
Trichoderma harzianum and & Bio-Fungus, Binab T, RootShield, T-22G, T-22 \\
other Trichoderma species & Planter Box, Bio-Trek, Promote, Supresivit, \\
& Trichodex, Trichopel, Trichoject, Trichodowels, \\
& Trichoseal, Trichoderma 2000 \\
\hline
\end{tabular}


Besides Trichoderma and Gliocladium species apathogenic Fusarium strains against phytopathogenic Fusaria [45], Coniothyrium strains against Sclerotinia [46] and Ampelomyces strains against powdery mildews [47] are used successfully for biocontrol, but few publications are dealing with their biochemical and genetic properties.

Many biocontrol filamentous fungi were patented and their registered on field use were permitted by the environmental agencies. Some important commercially available preparations are listed in Table I.

\section{Myconematocides and mycoinsecticides}

There are three types of nematophagous fungi. The first is able to produce trapping hyphae e.g. Arthrobotrys species [48], the conidia of second type are germinating on the surface of the nematode e.g. Verticillium [49] species, and in the third case the conidia are germinating in the intestinal system of the nematod e.g. Harposporium [50] species.

The trapping method of biocontrol is not reliable, as many environmental factors may disturb the differentiation of the trapping apparates [51].

An effective and widespread nematode biocontrol could be accomplished by the use of distinct strains of Verticillium lecanii, V. chlamydosporum and Paecilomyces lilacinus [52-53].

The most important factor of pathogenesis is the extracellular protease system both in Arthrobotrys, Verticillium and Paecilomyces species [54-56]. Verticillium, Arthrobotrys and Paecilomyces species besides their nematocidical effect, might also be effective against fungi and insects.

Many filamentous fungal genera contain insect parasitizing species. From them the species belonging to the Beauveria, Metarhizium, Verticillium and Paecilomyces are the most promising [79]. The effectiveness of the strains is related to the secretion of extracellular chitinases and proteinases; these enzyme systems are well characterized in the most strains [57].

The nematocide and insecticide strains were breeded by mutagenesis, protoplast fusion [58] and transformation [59-60]. In some cases structural genes of the degredative enzymes have been cloned [61-62].

There are possibilities for integrated control with chemical insecticides and fungicides by applying fungicide resistant strains.

The modern molecular methods, RFLP, PCR and RAPD for typing, identification and on field monitoring of strains are widely and successfully used [63-64].

Commercially Beauveria bassiana, Verticillium lecanii, Metarhizium anisopliae and Paecilomyces lilacinus are available. There are several products that contain $B$. bassiana, including Naturalis ${ }^{\circledR}$ and Mycotrol $^{\circledR}$. 


\section{Hungarian research activities}

In Hungary research activities related to fungal biological control are mainly limited to the Trichoderma genus. In his pioneering works Vajna has determined the distribution of Trichoderma species in Hungary and described some antagonistic isolates $[39,65]$.

Manczinger in Department of Microbiology, Attila József University, Szeged, investigated the catabolic abilities of many Hungarian isolates and detected species within the species aggregates with the use of assimilation spectra [66], also he explored the transient nature of the somatic diploid state in Trichoderma following protoplast fusion [26]. Recently in the microbial ecological working group of this department new biopesticid strains were produced by mutagenic treatment with excellent antagonistic properties [23] and for some T. harzianum and T. viride strains genetic transformation systems were established [29, 67-68]. Naár in the Department of Plant Science, Esterházy Teachers Training College, Eger investigates the ecological behavior of Trichoderma strains in distinct soil types, the effect of heavy metals to biocontrol Trichoderma strains and the possibilities for integrated pest management with Trichoderma strains [69-72]. Turóczi and others in the Department of Plant Pathology, Plant Protection Institute, Hungarian Academy of Sciences, Budapest and in the Agricultural Biotechnology Center, Gödöllô, respectively, in collaboration investigate the molecular characterization possibilities of Trichoderma strains [73-74] and recently they successfully cloned and transformed back a chitinase gene in T. hamatum [75].

\section{REFERENCES}

1. Lumsden,R.D.: Mycoparasitism of soilborne plant pathogens. In Carroll,G.C., Wicklow,D.T. (eds): The fungal community. Second edition. Marcel Dekker, New York. 1992. p. 275.

2. Adams,P.B.: The potential of mycoparasites for biological control of plant diseases. Annu Rev Phytopathol 28, 59 (1990).

3. Sivan,A., Chet,I: Microbial control of plant diseases. In Mitchell,R. (ed.): Environmental Microbiology. Wiley-Liss Inc., New York. 1992. p. 335.

4. Goldman,G.H., Hayes,C., Harman,G.E.: Molecular and cellular biology of biocontrol by Trichoderma spp. Trends Biotechnol 12, 478 (1994).

5. Samuels,G.J.: Trichoderma: a review of biology and systematics of the genus. Mycol Res 100, 923 (1996).

6. Claydon,N., Allan,M., Hanson,J.R., Avent,A.G.: Antifungal alkyl pyrones of Trichoderma harzianum. Trans Brit Mycol Soc 88, 503 (1987).

7. Wilhite,S.E., Straney,D.C.: Timing of gliotoxin biosynthesis in the fungal biological control agent Gliocladium virens (Trichoderma virens). Appl Microbiol Biotechnol 45, 513 (1996).

8. Di Pietro,A., Lorito,M., Hayes,C.K., Broadway,R.M., Harman,G.E.: Endochitinase from Gliocladium virens: isolation, characterization, and synergistic antifungal activity in combination with gliotoxin. Phytopathology 83, 308 (1993).

9. Thrane,C., Tronsmo,A., Jensen,D.F.: Endo-1,3-beta-glucanase and cellulase from Trichoderma harzianum: purification and partial characterization, induction of and biological activity against plant pathogenic Pythium spp. Eur J Plant Pathol 103, 331 (1997). 
10. de la Cruz,J., Rey,M., Lora,J.M., Hidalgo-Gallego,A., Dominguez,F., Pintor-Toro,J.A., Llobell,A., Benitez,T.: Carbon source control on beta-glucanases, chitobiase and chitinase from Trichoderma harzianum. Arch Microbiol 159, 316 (1993).

11. Ulhoa,C.J., Peberdy,J.F.: Regulation of chitinase synthesis in Trichoderma harzianum. J General Microbiol 137, 2163 (1991).

12. Haran,S., Schickler,H., Chet,I.: Molecular mechanisms of lytic enzymes involved in the biocontrol activity of Trichoderma harzianum. Microbiology 142, 2321 (1996).

13. Inbar,J., Chet,I.: Biomimics of fungal cell wall recognition by use of lectin coated nylon fibers. J Bacteriol 174, 1055 (1992).

14. Lorito,M., Harman,G.E., Hayes,C.K., Broadway,R.M., Tronsmo,A., Woo,S.L., Di Pietro,A.: Chitinolytic enzymes produced by Trichoderma harzianum: antifungal activity of purified endochitinase and chitobiosidase. Phytopathology 83, 302 (1993).

15. Harman,G.E., Hayes,C.K., Lorito,M., Broadway,R.M., Di Pietro,A., Peterbauer,C., Tronsmo,A: Chitinolytic enzymes of Trichoderma harzianum: purification of chitobiosidase and endochitinase. Phytopathology 86, 313 (1993).

16. Lima,L.H.C., Ulhoa,C.J., Fernandes,A.P., Felix,C.R.: Purification of a chitinase from Trichoderma sp. and its action on Sclerotium rolfsii and Rhizoctonia solani cell walls. J Gen Appl Microbiol 43, 31 (1997).

17. Pintor-Toro,J.A., Benitez,T., Llobell,A. : Purification and characterization of an endo-beta-1,6-glucanase from Trichoderma harzianum that is related to its mycoparasitism. J Bacteriol 177, 1864 (1995).

18. Schirmböck,M., Lorito,M., Wang, Y.L., Hayes,C.K., Arisan-Atac,I., Scala,F., Harman,G.E., Kubicek,C.P.: Parallel formation and synergism of hydrolytic enzymes and peptaibol antibiotics, molecular mechanisms involved in the antagonistic action of Trichoderma harzianum against phytopathogenic fungi. Appl Environ Microbiol 60, 4364 (1994).

19. Lorito,M., Peterbauer,C., Hayes,C.K., Harman,G.E.: Synergistic interaction between fungal cell wall degrading enzymes and different antifungal compounds enhances inhibition of spore germination. Microbiology 140, 623 (1994).

20. Ahmad,J.S., Baker,R.: Rhizosphere competence of benomyl-tolerant mutants of Trichoderma spp. Can J Microbiol 34, 694 (1988).

21. van Tilburg,A.U.B., Thomas,M.D.: Production of extracellular proteins by the biocontrol fungus Trichoderma virens. App Environ Microbiol 59, 236 (1993).

22. Sinha,I., Upadhyay,R.S.: Modification of biocontrol potential of Trichoderma viride. Acta Phytopathol Enthomol Hung 28, 209 (1993).

23. Manczinger,L., Antal,Zs., Ferenczy,L.: Breeding of mycoparasitic Trichoderma strains by UV-mutagenesis. Poster Abstracts, IUMS Congresses, Praha. 1994

24. Sivan,A., Harman,G.E.: Improved rhizosphere competence in a protoplast fusion progeny of Trichoderma harzianum. J Gen Microbiol 137, 23 (1991)

25. Stasz,T.E.: Genetic improvement of fungi by protoplast fusion for biological control of plant pathogens. Can J Plant Pathol 12, 322 (1990)

26. Manczinger,L., Ferenczy,L.: Somatic cell fusion of Trichoderma reesei resulting in new genetic combinations. Appl Microbiol Biotechnol 22, 72 (1985)

27. Stasz,T.E., Harman,G.E.: Nonparental progeny resulting from protoplast fusion in Trichoderma in the absence of parasexuality. Exp Mycol 14, 145 (1990).

28. Pe'er,S., Chet,I.: Trichoderma protoplast fusion: a tool for improving biocontrol agents. Can J Microbiol 36, $6(1990)$.

29. Manczinger,L., Komonyi,O., Antal,Zs., Ferenczy,L.: A method for high-frequency transformation of Trichoderma viride. J Microbiol Methods 29, 207 (1997).

30. Garcia,I., Lora,J.M., de la Cruz,J., Benitez,T., Llobel,A., Pintor-Toro,J.A.: Cloning and characterization of a chitinase (CHIT42) cDNA from the mycoparasitic fungus Trichoderma harzianum. Curr Genet 27, 83 (1994). 
31. Carsolio,C., Gutierrez,A., Jimenez,B., van Montagu,M., Herrera-Estrella,A.: Characterization of ech-42, a Trichoderma harzianum endochitinase gene expressed during mycoparasitism. Proc Natl Acad Sci USA 91, 10903 (1994).

32. Hayes,C.K., Klemsdal,S., Lorito,M., Di Pietro,A., Peterbauer,C., Nakas,J.P., Tronsmo,A., Harman,G.E.: Isolation and sequence of an endochitinase-encoding gene from a cDNA library of Trichoderma harzianum. Gene 138, 143 (1994).

33. Peterbauer,C.K., Lorito,M., Hayes,C.K., Harman,G.E., Kubicek,C.P.: Molecular cloning and expression of the nag1 gene (N-acetyl-beta-D-glucosaminidase-encoding gene) from Trichoderma harzianum P1. Curr Genet 30, 325 (1996).

34. Draborg,H., Christgau,S., Halkier,T., Rasmussen,G., Dalboge,H., Kauppinen,S.: Secretion of an enzymatically active Trichoderma harzianum endochitinase by Saccharomyces cerevisiae. Curr Genet 29, 404 (1966).

35. Draborg,H., Kauppinen,S., Dalboge,H., Christgau,S.: Molecular cloning and expression in Saccharomyces cerevisiae of two exochitinases from Trichoderma harzianum. Biochem Mol Biol Int 36, 781 (1995).

36. Geremia,R.A., Goldman,G.H., Jacobs,D., Ardiles,W., Vila,S.B., Van-Montagu,M., Herrera-Estrella,A.: Molecular characterization of the proteinase-encoding gene, prb1, related to mycoparasitism by Trichoderma harzianum. Mol Microbiol 8, 603 (1993).

37. de la Cruz,J., Pintor-Toro,J.A., Benitez,T., Llobell,A., Romero,L.C.: A novel endo-beta-1,3-glucanase, BGN13.1, involved in the mycoparasitism of Trichoderma harzianum. J Bacteriol 177, 6937 (1995).

38. Flores,A., Chet,H., Herrera-Estrella,A.: Improved biocontrol activity of Trichoderma harzianum by overexpression of the proteinase-encoding gene $p r b$-1. Curr Genet 31, 30 (1997).

39. Vajna,L.: Mutual parasitism between Trichoderma hamatum and Trichoderma pseudokoningii. Phytopathol Z 113, 300 (1985).

40. Upadhyay,R.S., Visintin,L., Jayaswal,R.K.: Environmental factors affecting the antagonism of Pseudomonas cepacia against Trichoderma viride. Can J Microbiol 37, 880 (1991).

41. Tronsmo,A., Dennis,C.: Effect of temperature on antagonistic properties of Trichoderma species. $\mathrm{Tr} \mathrm{Br}$ Mycol Soc 71, 469 (1978).

42. Schlick,A., Kuhls,K., Meyer,W., Lieckfeldt,E., Borner,T., Messner,K.: Fingerprinting reveals gamma-ray induced mutations in fungal DNA: implications for identification of patent strains of Trichoderma harzianum. Curr Genet 26, 74 (1994).

43. Arisan-Atac,I., Heidenreich,E., Kubicek,C.P.: Randomly amplified polymorphic DNA fingerprinting identifies subgroups of Trichoderma viride and other Trichoderma sp. capable of chestnut blight biocontrol. FEMS Microbiol Lett 126, 249 (1995).

44. Bulat,S.A., Lübeck,M., Mironenko,N., Jensen,D.F., Lübeck,P.S.: UP-PCR analysis and ITS1 ribotyping of strains of Trichoderma and Gliocladium. Mycol Res 102, 933 (1998).

45. Mandeel,Q., Baker,R.: Mechanisms involved in biological control of Fusarium wilt of cucumber with strains of nonpathogenic Fusarium oxysporum. Phytopathology 81, 462 (1991).

46. McQuilken,M.P., Whipps,J.M.: Production, survival and evaluation of solid-substrate inocula of Coniothyrium minitans against Sclerotinia sclerotiorum. Eur J Plant Pathol 101, 101 (1995).

47. Falk,S.P., Gadoury,D.M., Cortesi,P., Pearson,R.C., Seem,R.C.: Parasitism of Uncinula necator cleistothecia by the mycoparasite Ampelomyces quisqualis. Phytopathology 85, 794 (1995).

48. den Belder,E., Jansen,E.: Saprophytic and predacious abilities in Arthrobotrys oligospora in relation to dead and living root-knot nematodes. Fundamental Appl Nematol 17, 432 (1994).

49. Kerry,B.R.: Ecological considerations for the use of the nematophagous fungus, Verticillium chlamydosporium, to control plant parasitic nematodes. Can J Botany 73, S65 (1995).

50. Glockling,S.L., Dick,M.W.: A new species of Harposporium infecting Rhabditis nematodes with microspores. Mycol Res 98, 854 (1994).

51. Quinn,M.A.: The influence of saprophytic competition on nematode predation by nematode-trapping fungi. J Invertebr Pathol 49, 170 (1987). 
52. Meyer,S.L.F., Huettel,R.N.: Application of a sex pheromone, pheromone analogs, and Verticillium lecanii for management of Heterodera glycines. J Nematology 28, 36 (1996).

53. Gaspard,J.T., Jaffee,B.A., Ferris,H.: Meloidogyne incognita survival in soil infested with Paecilomyces lilacinus and Verticillium chlamydosporium. J Nematology 22, 176 (1990).

54. Tunlid,A., Jansson,S.: Proteases and their involvement in the infection and immobilization of nematodes by the nematophagous fungus Arthrobotrys oligospora. Appl Environ Microbiol 57, 2868 (1991).

55. Butt,T.M., Keen,J.N., Kerry,B.R., Peberdy,J.F.: The subtilisins of the invertebrate mycopathogens Verticillium chlamydosporium and Metarhizium anisopliae are serologically and functionally related. FEMS Microbiol Lett 126, 227 (1995).

56. Bonants,P.J.M., Fitters,P.F.L., Thijs,H., den Belder,E., Waalwijk,C., Henfling,J.W.D.M.: A basic serine protease from Paecilomyces lilacinus with biological activity against Meloidogyne hapla eggs. Microbiology 141, 775 (1995).

57. St Leger,R.J., Joshi,L., Roberts,D.W: Adaptation of proteases and carbohydrases of saprophytic, phytopathogenic and entomopathogenic fungi to the requirements of their ecological niches. Microbiology 143, 1983 (1997).

58. Couteaudier,Y., Viaud,M., Riba,G.: Genetic nature, stability, and improved virulence of hybrids from protoplast fusion in Beauveria. Microb Ecol 32, 1 (1996).

59. Bogo,M.R., Vainstein,M.H., Aragao,F.J.L., Rech,E., Schrank,A.: High frequency gene conversion among benomyl resistant transformants in the entomopathogenic fungus Metarhizium anisopliae. FEMS Microbiol Lett 142, 123 (1996).

60. Goettel,M.S., Leger,R.J.S., Bhairi,S., Jung,M.K., Oakley,B.R., Roberts,D.W., Staples,R.C.: Pathogenicity and growth of Metarhizium anisopliae stably transformed to benomyl resistance. Curr Genet 17, 129 (1990).

61. St Leger,R.J., Bidochka,M.J.: Cloning of a cuticle-degrading protease from the entomopathogenic fungus, Beauveria bassiana. FEMS Microbiol Lett 125, 211 (1995).

62. Smithson,S.L., Paterson,I.C., Bailey,A.M., Screen,S.E., Hunt,B.A., Cobb,B.D., Cooper,R.M., Charnley,A.K., Clarkson,J.M.: Cloning and characterisation of a gene encoding a cuticle-degrading protease from the insect pathogenic fungus Metarhizium anisopliae. Gene 166, 161 (1995).

63. Leal,S.C.M., Bertioli,D.J., Butt,T.M., Peberdy,J.F.: Characterization of isolates of the entomopathogenic fungus Metarhizium anisopliae by RAPD-PCR. Mycol Res 98, 1077 (1994).

64. Hegedus,D.D., Khachatourians,G.G.: Identification and differentiation of the entomopathogenic fungus Beauveria bassiana using polymerase chain reaction and single-strand conformation polymorphism analysis. J Invertebr Pathol 67, 289 (1996).

65. Vajna,L.: Trichoderma species in Hungary. Acta Phytopathol 18, 291 (1983).

66. Manczinger,L., Polner,G.: Cluster analyses of carbon source utilization patterns of Trichoderma isolates. System Appl Microbiol 9, 214 (1987).

67. Manczinger,L., Antal,Zs., Ferenczy,L.: Isolation of uracil auxotrophic mutants of Trichoderma harzianum and their transformation with heterologous vectors. FEMS Microbiol Lett 130, 59 (1995).

68. Antal,Zs., Manczinger,L., Ferenczy,L.: Transformation of a mycoparasitic Trichoderma harzianum strain with the $\arg B$ gene of Aspergillus nidulans. Biotechn Techn 11, 205 (1997).

69. Naár,Z., Kecskés,M.: Factors influencing the colonization of different Trichoderma species in the soil. (in Hungarian) Agrokémia és Talajtan 44, 221 (1995).

70. Naár,Z., Várady,Gy., Kucsma,N., Kecskés,M.: Cadmium susceptibility of Trichoderma strains. (in Hungarian) Agrokémia és Talajtan 44, 457 (1995).

71. Naár,Z., Kecskés,M.: A method for selecting trichoderma strains antagonistic against Sclerotinia minor. Microbiol Res 150, 239 (1995).

72. Naar,Z., Kecskés,M.: Factors influencing the competitive saprophytic ability of Trichoderma species. Microbiol Res 153, 119 (1998). 
73. Fekete,Cs., Weszely,T., Hornok,L.: Assignment of a PCR-amplified chitinase sequence cloned from Trichoderma hamatum to resolved chromosomes of potential biocontrol species of Trichoderma. FEMS Microbiol Lett 145, 385 (1996).

74. Turóczi,G., Fekete,Cs., Kerényi,Z., Nagy,R., Pomázi,A., Hornok,L.: Biological and molecular characterisation of potential biocontrol strains of Trichoderma. J Basic Microbiol 36, 63 (1996).

75. Giczey,G., Kerényi,Z., Dallmann,G., Hornok,L.: Homologous transformation of Trichoderma hamatum with an endochitinase encoding gene, resulting in increased levels of chitinase activity. FEMS Microbiol Lett 165, 247 (1998).

76. Ulhoa,C.J., Vainstein,M.H., Peberdy,J.F.: Transformation of Trichoderma species with dominant selectable markers. Curr Genet 21, 23 (1992).

77. Esposito,E., Silva,M:: Systematics and environmental application of the genus Trichoderma. Crit Rev Microbiol 24, 89 (1998).

78. Kubicek,C.P.: Trichoderma and Gliocladium: Enzymes, biological control, and commercial applications. Taylor and Francis, 1998.

79. Leathers,T.D., Gupta,S.C., Alexander,N.J.: Mycopesticides : status, challanges and potential. J Ind Mirobiol 12, 69 (1993).

80. Handelsman,J., Stabb,E.V.: Biocontrol of soilborne plant pathogens. Plant Cell 8, 1855 (1996). 